\title{
The Limits of Individual-Level Factors for Ghanaian and South African Girls' Learning
}

\author{
Sally A. Nuamah
}

\section{The Barriers to LetTing Girls Learn}

While girls struggle to enter school, many also struggle to stay in school (Glick \& Sahn, 2000). Research on African girls consistently shows that girls miss several days of school per month for a plethora of gender-based responsibilities related to domestic work (United Nations Educational Scientific Cultural Organization [UNESCO], 2014). These are the same responsibilities that make them vulnerable to never returning to school once they are forced to take a gap year due to lack of enrollment spaces. With the re-emergence of three-year education in Ghana, for example, a typical girl must wait one to two years before entering the next stage of her education. During this wait, girls often veer off course in irreparable ways.

In particular, girls get discouraged from applying and often fall victim to early marriage and pregnancy. Their families, many of which are already

\section{S. A. Nuamah $(\bowtie)$}

School of Education and Social Policy, Northwestern University, Evanston, IL, USA

e-mail: sally.nuamah@northwestern.edu

(C) The Author(s) 2020

M. L. McLean (ed.), West African Youth Challenges and

Opportunity Pathways, Gender and Cultural Studies in Africa and the Diaspora, https://doi.org/10.1007/978-3-030-21092-2_8 
uncertain about the value of education, lose sight of the end goal as the girl student may begin to contribute to the family full time as a petty trader. Once families get used to her contribution, they do not want to revert to a period when she did not contribute in lieu of the delayed gratification associated with a four-year college degree, for a girl who will likely get married off anyway. Thus, a girl may have the choice of either getting married so that she is no longer a resource drain on her already poor family or directly contributing to their survival by not going to college but rolling up her sleeves and working. Many guardians discourage college or completion with reasoning such as "you have had enough education" and "you have to come back home and help the family now." Furthermore, when they seek to return, girls suffer from lower exam scores, making admission into the next level of education more difficult when compared to boys.

\section{Confidence as a Potential Solution?}

One critical effect of negative experiences with school and community is that it lowers girls' confidence. In the United States, there is significant research on the role of individual-level factors such as confidence in shaping educational and career outcomes for girls, despite the above barriers (American Association of University Women [AAUW], 1995; Kay \& Shipman, 2014). Similarly, in Ghana, country-level analysis reveals that as girls enter high school they experience a decline in their confidence and subsequently their mathematics performance, despite demonstrating equally positive attitudes toward math as boys during junior high school (Asante, 2010; Nyala, 2008). Furthermore, results from another study of 500 ninth grade (high school) students from the central region of Ghana found that students expressed high interest and value for math but shared a need for more confidence from their teachers in their mathematics ability and more encouragement for them to develop interest (Ampadu, 2012). The multiple studies on the impact of confidence have spurred initiatives to increase the confidence of girls across the Global North and South as a solution to achievement.

At the same time, Black girls display a high level of confidence in math and science, compared with their majority counterparts, but they struggle to achieve at the same level as these groups (Riegle-Crumb, Moore, \& Ramos-Wada, 2011). In addition, although confidence narrows gender gaps for girls in Ghana, they still fail to close them (Mullis, Martin, Foy, \& Arora, 2012). This suggests that there is a need to look beyond 
individual-level factors such as confidence for improving the educational outcomes of girls. I argue that confidence, and likely any other single factor alone, is not enough to enable the collective achievement of girls. Rather, female students need self-belief (which confidence feeds into) and strategies to respond to challenges. However, most importantly, they need institutions that intentionally create environments that eliminate the gendered barriers that students face.

In this chapter, I analyze data from 30 interviews and a targeted survey in Ghana and South Africa. These are African countries with a clear, legal commitment to gender equality. Still, they both struggle to ensure their girls (1) are performing well academically (Mullis et al., 2012; Reddy et al., 2016), (2) have the resources they need in schools, such as toilets and clean water (UNESCO, 2015), and (3) have the quality of education they deserve. While I acknowledge that making direct comparisons remain difficult given the middle-income status of South Africa and the lowerincome status of Ghana, I examine the role of confidence in shaping learning in South Africa, before using the findings to evaluate an intervention in the case of Ghana. In doing so, I highlight the factors needed to let girls learn across these contexts.

\section{A Case Study of Limpopo in South Africa}

In 2014, in collaboration with members of the Human Sciences Research Council, I investigated secondary schools in South Africa that serve mostly disadvantaged students (K-12) and yet are successful in transforming them into academically successful learners. The study found that, despite the challenging conditions experienced by students at these particular schools, $88 \%$ of students reported liking school (12\% higher than the population average), $63 \%$ indicated that they felt safe at school, and $60 \%$ felt a sense of belonging at their specific school. The research placed particular focus on the schools in one of South Africa's nine provinces, Limpopo. Limpopo is a largely rural area in the northernmost part of the country. It is one of South Africa's poorest provinces, with nearly $80 \%$ of its population living below the poverty line. It is also home to the largest Black population in the entire country, with them making up $97 \%$ of the population.

Out of South Africa's 11.4 million students, 2 million are in Limpopo. In 2015 , students in the province scored among the lowest, with $76 \%$ of its learners scoring below the low benchmark of 400 , compared to $60 \%$ for the country. Overall, the passing rate of all Limpopo students is below the 
national average across grade levels, and girls' passing rates in Limpopo are even lower than the national girls' average (National Department of Basic Education, 2016). Similar to national patterns, a higher percentage of girls in Limpopo sit to take the college matriculation exam than boys (53\% versus $47 \%)$. Yet, fewer girls than boys pass (70\% versus $77 \%)$. As illustrated by the cases discussed in this chapter, fewer girls than boys qualify for higher degree programs, likely due to a number of gender-based barriers.

To overcome these challenges, quality schools in Limpopo strive to create environments that offer creative solutions and are dedicated to their students' achievement. These schools often offer girls a high number of additional classes and course work before and after school. Educators in these Limpopo schools try to make complex courses such as math practical, share resources with teachers at other schools, work with students on homework before they go home, and attempt multiple techniques to encourage parents and grandparents to be involved by sharing their children's successes and challenges. These additional efforts have enabled schools in Limpopo in 2015 to experience immense growth, particularly in mathematics and science, relative to every other province (Reddy et al., 2015). Although in 2015 Limpopo scored 361st in math and thus ranked as the fourth lowest province, it has achieved the highest gains, compared with other provinces, in math and science since 2003. These services are provided to both boys and girls and positively impact both groups.

\section{A SAFE SCHOOL}

One particular secondary school in Limpopo stood out in my study for its ability to improve both overall academics and the experiences of girl learners, in turn creating a safe space to learn. From the onset of the study, it was clear that Mapate Elementary represented the surest sign of Limpopo's progress. The school benefited from a principal that engaged the community to view Mapate as an asset that they were all responsible for protecting. Principal Matthew Bokamaso used this approach to make the broader community, rather than just the school staff, responsible for the success of the students at the school. The result was a community that took ownership and created the conditions that ensured learners had a safe environment in which they could achieve.

To facilitate a safe space, Principal Bokamaso emphasized to his teachers the importance of treating the students with the same level of urgency they would their own kids. As he stated: 
I am a parent. I have a child and you also have a child ... and our responsibility here is to make sure that each learner here gets everything our children get ... And if you find me doing something that is contrary, don't do that. If you see me do it, you tell me straight that, "Sir, this is not what we are supposed to do."

Principal Bokamaso stresses this point to teachers, staff, and parents in order to promote a more community-based approach to caring for the students, to emphasize the level of responsibility this requires, and to institute accountability in achieving this approach. This supportive learning environment becomes critical for ensuring the students at the school can develop the achievement-oriented identities-confidence, strategy, transgression-necessary for confronting and overcoming personal and academic challenges (Nuamah, 2019).

Achievement-oriented identities are not created easily in Limpopo or in, Mapate, specifically. Because of Limpopo's economic status, its schools lack basic resources such as books and paper. Principals often report teaching a full load of courses in addition to their administrative responsibilities. School cancellations are commonplace when it rains because it is too hard to access the entrance through muddy, unpaved roads. The schools are also filled with students who are just as impoverished.

Another challenge is the low education level of many of the students' parents or household guardians, which directly shapes the children's preparation level and the parents' or guardians' ability to help children with their schoolwork. In fact, many students' parents or grandparents were products of the Bantu Education Act and lack the formal education they are seeking to give to their kids and grandkids. As one teacher stated in response to the question of challenges facing her school, "The challenges for the learners is that they stay alone or with grandparents, and most of the adults in the families are illiterate so they can't help students complete their homework." When parents or guardians are unable to help at home, teachers make up for this by offering extra classes and encouraging students to complete their homework before they head home. This results in improved academics, as one first-grade teacher, on the job for 23 years, noted, "When learners come here, they are unable to read and write. Counting for students is a challenge, even simple numbers. I deal with this by giving extra classes ... before they go home." 
Beyond providing extra courses and encouraging students to come early or stay late after classes, teachers work to engage parents as well. The head of the math department at Mapate, for example, shared that he encourages parents to get involved by calling them if students do well as a mechanism to build rapport and trust. Furthermore, he prioritizes finding ways for parents to directly contribute to improving the educational practices of their children, even if they themselves are not educated. Accordingly, he provides parents with tangible tools for helping their kids. In the words of this teacher, "At the beginning when parents collect books, each parent will be carrying a packet of books and an assessment plan for the whole year for the child."

The rest of this chapter will detail Mapate's efforts using data derived from 30 interviews conducted between 2013 and 2014 in English. In the interviews, there were constant references to the multiple stakeholders involved in ensuring that disadvantaged students succeed. As stated by one of Mapate's school leaders, "There are three parties involved in education: the learners, the parents, and the educators ... the school has a uniting role. Each party puts on the table their level of commitment to ensure they will perform well." Schools recognize that they cannot ensure the achievement of their students without the support of the broader community, and, thus, their ability to bring these multiple partners together becomes an essential starting point for building academically successful students. Once stakeholders are convened, the school works to identify its students academic challenges.

To gauge the students' specific academic challenges, Mapate first meticulously documents their progress:

On weekly basis, there is a report that must be submitted by the [head of department]. I must see how we are doing. It contains what the learners are [doing] in math and all those things ... and that works.

Second, each week teachers are updated on the learning outcomes of their students, and strategies to help those students are discussed and shared. These small actions keep everyone accountable for the academic fate of each student and encourage teachers to become invested in helping each other as well as the students. Principal Bokamaso then conducts class visits to provide feedback on teaching practices.

The most veteran teacher in the study is Ms. Magda, who had been working in Limpopo schools teaching math and a local language for 26 years. She specified other important factors for helping students from poor backgrounds achieve, despite low resources and education at the school. 
In addition to emphasizing extra classes, she stressed the importance of making herself available for students to "approach her about everything," "coming down to their level and making sure that learners are not afraid" of her, "making them believe that math is easy and all a student has to do is believe that," and being committed to using "practical examples to illustrate the problem." Her methods epitomize the type of environment necessary for facilitating achievement-oriented identities among students, as they enable students, especially girls, to feel confident in their abilities to both tackle the hardest subjects, such as math, and present concerns that are important to them in order to develop solutions to address them.

\section{Reframing Failure to Help Girls Learn}

Girls that attend school at Mapate struggle initially to make substantial progress, even under the guidance of teachers like Ms. Magda. While some girls overcome both personal and academic struggles to become model students for the school, other girls struggle to achieve as easily, particularly in math and science. To improve achievement in math, Principal Bokamaso and teachers at the Mapate school decided to teach students to apply math to their real-world experiences, in the process also teaching them how to become achievement oriented. Principal Bokamaso had noticed a disconnect between how math is used in the classroom and how it is used practically in the real world:

If [a girl student] goes to the market with 100 rand and buys something that costs 27 rand, that learner will know that [her] change is 73 rand, but if you ask the same question in the classroom, [she] does not get it right. It seems what we are teaching is removed from reality.

Principal Bokamaso did not view students' inability to connect math in the real world to math in the classroom as an incompetency due to gender or innate ability; instead, he viewed it as an area where educators could improve their curriculum and teaching. Principal Bokamaso also wanted students to understand that failure in the classroom can be beneficial. As he tells his students, "People who struggle in the classroom become more successful because they are used to the wrongs. A guy who fails every class will repeat until he finds another strategy. Once you fail, you don't give up." Framing failure as an asset essential for success becomes fundamental for enabling girl students' self-belief, a critical factor for developing 
achievement-oriented identities. Instead of viewing their challenges as ones they cannot overcome, girls at Mapate are encouraged to believe that there is always another strategy they can engage in and utilize to succeed the next time around. For girl students who are vulnerable in a number of ways, this message acts as a powerful tool for helping them find proactive ways to confront their barriers.

Being intentional about gender dynamics within the classroom is especially important for ensuring the achievement of girls. In fact, studies show that girls in co-ed schools may struggle with subjects such as science due to fear of answering questions incorrectly, while boys may not hold this fear at all (Sadker \& Sadker, 2010; Shapka \& Keating, 2003). Girls often need to be assured that it is okay to be wrong. It is unsurprising then that one teacher at Mapate says, "There is no wrong answer in science. We only make mistakes and then we correct the mistake. [Students] have told [me] that science is difficult, but I tell my learners, it is practical." Undoubtedly, schools must create environments where all students feel comfortable participating, even if they are wrong, as a central mechanism for achieving gender equality. Once students remove the fear of failure, they more easily find a pathway to confidence, a fundamental aspect of building achievementoriented identities.

\section{Building Achievement-Oriented Identities in Ghana}

In another study, I evaluated a gap-year program in a poor slum in Accra, Ghana, that sought to prepare girls who were not admitted into college to reapply between 2016 and 2018. A total of 33 girls were included in the program, 7 of whom participated in the gap-year program. The age of the girls ranged from 16 to 22. Each of the girls attended a government subsidized school located in Accra. Each of the girls was selected through an application process. Those that were admitted into college were provided with college scholarships and mentorship workshops. Those who were not admitted were provided with remedial test prep (the gap-year program) and mentorship workshops. The girls were surveyed throughout the year. The program was developed to try to support girls' college entry and to institute identities that would enable first generation girls to become confident based, in part, on what was learned in the case of Limpopo. The program was funded through resources provided through a small grant by the Ford Foundation and the International Education Program. 
Overall, the findings reveal that girls need not only confidence in a subject area, but also the resources necessary for the test and strategies to study for it. Several girls reported that they felt they "did not have enough time to study," or that "teachers were moving too quickly." In addition, girls who had "unlimited access to wifi ... [and] free 24-hour libraries" reported more confidence in their ability to go over difficult homework problems, while those who did not professed their desire to have more time in small groups outside of class to go over work problems. Many girls commended the long period of time provided to prep for an exam, as it made them feel they had time to prepare; however, for those who had to work due to needed finances at home, there were diminishing returns as the class demand increased. These students also reported the challenge of "not having a personal laptop as a non-resident [and] not being able to access internet facilities" or afford books. In one case, a student fell sick and missed multiple classes, thereby disrupting the progress she had made right before taking the exam. It was a challenge to get her back on track before the scheduled exam. In the future, it is important to be able to better schedule make-up opportunities to account for these types of unexpected events.

Generally, there were strong reasons to suspect that conducting independent classes would produce stronger outcomes, as it would facilitate better regulation of the program quality. However, with populations that are already so vulnerable, this would likely be very expensive. It is clear that the students who were in remedial courses were academically lower than the other girls in the program and faced an additional set of challenges at home. Thus, it became clear that it was also important to consider how organizations may be able to supplement the incomes of these students over the long term to allow them to focus on their studies.

Given these constraints, the goal of keeping students in the college pathway was met. Each of the students expressed a continued desire to go to a four-year college and had increased grit scores. Many of the students also realized the different tools they would need before entering college and how those tools were in some ways different than what they needed in high school. As one student reported, "It's all about time management and confidence in yourself to undertake certain things." Additional positives of the program include being able to keep girls who were most at risk of never attending college still on track to their college dreams. Each of the girls who participated in the program is writing the college entry exam and maintaining an interest in attending college. Not 
a single girl dropped out of the program, and attendance was high from start to finish for $90 \%$ of the participants. The confidence-building mentorship workshops were an even bigger success. Girls spent their entire Saturday learning from established women and their peers who are already in college about important issues related to their future. At these meetings, they were encouraged to continue to strive for their goals. When they were surveyed at the end of the program, each girl noted an increased confidence in their capacity to enter college. Nonetheless, their objective conditions had not changed. These conditions limited their ability to attend college, despite their heightened confidence levels.

\section{Letting All Students Learn}

Across the data collected for this research, it appears that the most successful tools for all students centered on the following themes in their everyday practices: passionate teachers, community, love, self-belief, and academic excellence.

\section{- Passionate Teachers}

Teachers serving some of the poorest students in the nation must go well above their normal load in order to help their students catch up and achieve. Thus, a stand-out quality among those who are able to help poor learners excel is a sense of urgency about their role in the lives of their students. Teachers must have important internal justifications to rationalize what may seem like a tireless effort. It requires a fundamental belief that the students see education as their pathway to a better future. Even so, teachers recognize that they are not able to simply help students out of mere passion alone. Instead, they need to bring together various members of the community to invest in the success of the student.

\section{- Community}

There were constant references across the data to the multiple stakeholders involved in ensuring that disadvantaged students succeed. School leaders commonly referenced the importance of uniting students, educators, and families for the sake of the educational success of the student. Schools recognize that they cannot ensure the achievement of their students without the support of the broader community, and, thus, their ability to bring these multiple partners together becomes an essential starting point for building academically successful students. 


\section{- Love and Self-love}

Two important parts of building community for students at school is infusing love and self-love within them. Students who are successful often expressed feeling loved by their educational communities, and part of how they make that determination is through examples of how that educator helped them believe in themselves. This notion of love being intentionally espoused by school teachers and directly felt by students and their parents plays a critical role in building achievement-oriented identities among the student population. When students experience these actions from their teachers, they are also being taught how to treat others, which introduces an important opportunity for practicing gender equality in the classroom.

\section{- Academic Excellence}

There is no clear, single way to help girl students achieve academic excellence, but it is clear that at a basic level there are two main values: hard work and discipline. Many schools pitch these pillars to students as the magic solution to changing their situation. And, indeed, students take on these tropes and come to associate them with everything they do. To ensure that girl students remain encouraged through the various setbacks they are likely to endure, even if they work hard, these schools emphasize the importance of not comparing themselves to one another but rather helping each other and competing only with oneself.

Each of these tactics plays a critical role in developing girl students who have a strong sense of self-belief and self-efficacy as well as the tools to think and respond to their challenges.

Yet, none of these factors removes the structural barriers that impede girls' ability to experience equitable academic experiences and life outcomes: In South Africa, 14-year-old Amahle is leaving school for the day when a man approaches her. He tells her to come with him, that her aunt has arranged for her to marry him. As Amahle notes in her own words:

I tr[ied] to tell him that I must go and get my things, because I was thinking it would give me time to run away, but he said no and forced me into the car. I was afraid and knew I had my rights. (Wilson, 2006, p. 10) 
This is not something that happened decades ago. Rather, this is a recent, true story of a schoolgirl being forced into an arranged marriage with a 43-year-old man by her own aunt without her consent. Indeed, Amahle did know her rights, thanks to the Girls Education Movement (GEM), a program formed in 2003 by the Ministry of Education in South Africa to build knowledge and self-esteem among girls, but in that moment, there was nothing she could do.

Amahle's story is important for several reasons. First, it demonstrates how gender-based violence in South Africa can, and often does, occur in and around the schoolhouse. Second, it highlights how important it is for girls to be informed of their rights and be empowered to speak up. For Amahle, her involvement in GEM played a critical role in providing her with the tools to at the very least attempt to defend herself, but structural changes are necessary for her to not have to deal with these issues to start.

\section{Conclusion}

Across both countries, confidence matters (as do other factors). Still, as expected, it is conditional on various aspects of structural inequality, whether related to parental education, individual- or school-level economic status, or school experience (Nuamah, 2018). Most importantly, girls across these contexts are dealing with unequal gender relations that actively chip away at confidence rather than build it. Given the various factors affecting girls' educational achievement, the analysis of the data raises more questions than it answers. Yet, a clear takeaway is that a singular effort focused on building confidence to close the achievement gap by race and/or gender is not enough. Improving individual achievement through confidence, or any other similar factor, cannot save every girl student (Nuamah, 2019).

\section{REFERENCES}

American Association of University Women (AAUW). (1995). How schools shortchange girls: The AAUW report. New York, NY: Marlowe.

Ampadu, E. (2012). Students' perceptions of their teachers' teaching of mathematics: The case of Ghana. International Online Journal of Educational Sciences, 4(2), 351-358.

Asante, K. O. (2010). Sex differences in mathematics performance among senior high students in Ghana. Gender and Behaviour, 8(2), 3279-3289. 
Glick, P., \& Sahn, D. E. (2000). Schooling of girls and boys in a West African country: The effects of parental education, income, and household structure. Economics of Education Review, 19(1), 63-87.

Kay, K., \& Shipman, C. (2014). The confidence gap. The Atlantic, 14(1), 1-18.

Mullis, I. V., Martin, M. O., Foy, P., \& Arora, A. (2012). TIMSS 2011 international results in mathematics. Amsterdam: International Association for the Evaluation of Educational Achievement.

National Department of Basic Education. (2016). Education statistics in South Africa 2014. Pretoria: Department of Education. Retrieved July 21, 2018, from www.education.gov.za/EMIS/StatisticalPublications/tabid/462/Default.aspx

Nuamah, S. A. (2018). Achievement oriented: Developing positive academic identities for girl students at an urban school. American Educational Research Journal, 55(6), 1307-1338. https://doi.org/10.3102/0002831218782670

Nuamah, S. A. (2019). How girlsachieve. Cambridge, MA: Harvard University Press.

Nyala, J. I. (2008). Sex-differences in attitude towards mathematics of junior high school students in Ghana. Edo Journal of Counselling, 1(1), 137-161.

Reddy, V., Visser, M., Winnaar, L., Arends, F., Juan, A. L., Prinsloo, C., et al. (2016). TIMSS 2015: Highlights of mathematics and science achievement of grade 9 South African learners. Pretoria: Human Sciences Research Council.

Reddy, V., Zuze, T. L., Visser, M., Winnaar, L., Juan, A., Prinsloo, C. H., et al. (2015). Beyond benchmarks: What twenty years of TIMSS data tell us about South African education. Pretoria: Human Sciences Research Council Press.

Riegle-Crumb, C., Moore, C., \& Ramos-Wada, A. (2011). Who wants to have a career in science or math? Exploring adolescents' future aspirations by gender and race/ethnicity. Science Education, 95(3), 458-476.

Sadker, M., \& Sadker, D. (2010). Failing at fairness: How America's schools cheat girls. New York, NY: Simon and Schuster.

Shapka, J. D., \& Keating, D. P. (2003). Effects of a girls-only curriculum during adolescence: Performance, persistence, and engagement in mathematics and science. American Educational Research Journal, 40(4), 929-960.

United Nations Educational Scientific Cultural Organization (UNESCO). (2014). Puberty education \& menstrual hygiene management. Retrieved October 21, 2018, from http://unesdoc.unesco.org/images/0022/002267/226792e.pdf United Nations Educational Scientific Cultural Organization (UNESCO). (2015). Education for all 2000-2015: Achievements and challenges (Global Monitoring Report 2015). Retrieved October 21, 2018, from http://unesdoc.unesco. org/images/0023/002322/232205e.pdf

Wilson, F. (2006). Gender based violence in South African schools. Paris: International Institute for Educational Planning. 
Open Access This chapter is licensed under the terms of the Creative Commons Attribution 4.0 International License (http://creativecommons.org/licenses/ by $/ 4.0 /)$, which permits use, sharing, adaptation, distribution and reproduction in any medium or format, as long as you give appropriate credit to the original author(s) and the source, provide a link to the Creative Commons licence and indicate if changes were made.

The images or other third party material in this chapter are included in the chapter's Creative Commons licence, unless indicated otherwise in a credit line to the material. If material is not included in the chapter's Creative Commons licence and your intended use is not permitted by statutory regulation or exceeds the permitted use, you will need to obtain permission directly from the copyright holder.

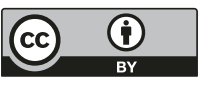

